\title{
"COURAGEOUS BUT INSOLENT": African soldiers in the Dutch East Indies as seen by Dutch officials and Indonesian neighbours
}

\author{
Transforming Cultures eJournal, \\ Vol. 4 No 2 November 2009 \\ http://epress.lib.uts.edu.au/journals/TfC
}

\section{Ineke van Kessel ${ }^{1}$}

\begin{abstract}
Labour shortages were endemic in colonial societies. Plantation and mining labour was notoriously unattractive, but the army posed problems of its own. In their search to satisfy the voracious appetite for labour in commercial empires and colonial societies, rulers developed racial and ethnic stereotypes as to which "race" was most suitable to perform certain jobs. Africans were deemed most suitable for hard physical labour in tropical climates. They were also portrayed as "martial races", fit to fill the manpower needs of both Islamic and European armies. ${ }^{2}$ This article will first give a brief overview of the use of African labour in the Dutch East Indies. Next, I discuss in more detail one peculiar aspect of inter-colonial labour migration in the Dutch colonial empire: the recruitment of West African soldiers for the Dutch East Indies army in the $19^{\text {th }}$ century.

[Africa, Indonesia, colonialism]
\end{abstract}

\section{Introduction}

Recruiting labour from West Africa for Southeast Asia deviated from the established pattern of the slave trade in the Indian Ocean world. As part of the Atlantic world, in the Dutch commercial system West Africa belonged to the domain of the West India Company (WIC). East of the Cape of Good Hope, the Dutch East India Company

\footnotetext{
${ }^{1}$ Ineke van Kessel is an historian at the African Studies Centre, Leiden, The Netherlands. She focuses mainly on contemporary social and political movements in South Africa, as well as the historical relations between the Netherlands and the Gold Coast. Her latest books are Zwarte Hollanders: Afrikaanse soldaten in Nederlands Indië, Amsterdam, 2005, and an edited volume (with Stephen Ellis), Movers and Shakers: Social Movements in Africa, Leiden/Boston, 2009.

${ }^{2}$ For the use of Africans as soldiers in Islamic armies, see: R. Segal (2001) Islam's Black Slaves: a History of Africa's Other Black Diaspora, London.
} 
(VOC) connected East Africa with South Asia and South East Asia. As Shihan de Silva Jayasuriya notes:

Dutch slavery integrated the Indian Ocean Basin drawing slaves from Africa (East Africa, Madagascar, Mascarene Islands), South Asia (Malabar, Coromandel and the Bengal/Arakan coast) and South East Asia (Malaysia, Indonesia, New Guinea and the Philippines). The Dutch Indian Ocean slave system, therefore, drew captive labour from three interlocking and overlapping circuits or subregions. ${ }^{3}$

Dutch officials considered Africans to be particularly suited for hard labour and they were generally employed as field labourers, growing grains, cotton, tobacco and other crops. De Silva Jayasuriya herself has published on the employment of Africans as construction workers and soldiers during Dutch and British rule in Ceylon. On $18^{\text {th }}$ century Dutch maps of Colombo, an area in the present city centre is marked Kaffers Veldt (Kaffirs' Field). In Sri Lanka, it is still possible to trace remnants of African heritage among Afro-Sri Lankans, but African immigration to the Dutch East Indies in the age of company rule has left no visible traces. By contrast, $19^{\text {th }}$ century African migration to the East Indies can be traced in detail in archives and in oral traditions told by descendants.

In terms of labour migration in the Dutch colonial empire in the days of company rule, the Atlantic slave trade has obviously received the bulk of scholarly and popular attention. The Dutch entered the slave trade to meet the labour needs of the short-lived colony of Dutch Brazil (1624-1654), and continued to supply the plantations in Surinam and the Netherlands Antilles, as well as several slave markets in the Caribbean. In Africa, it was the VOC (Vereenigde Oostindische Compagnie -Dutch East India Company) settlement at the Cape of Good Hope that consumed most manpower. The Cape was sparsely populated by nomadic Khoikhoi who resisted being drawn in as labourers for the VOC. The vast majority of slaves imported to the Cape were drawn from the Indian Ocean basin. It has been estimated by historians that in the period between 1657 and 1808 (British prohibition of the oceanic slave trade), 62,964 slaves were brought to the Cape. Robert Shell has calculated their regions of origin. He estimates that some $22 \%$ of slaves at the Cape originated from present-day

\footnotetext{
${ }^{3}$ S. de Silva Jayasuriya (2007) "A Forgotten Minority: The Afro-Sri Lankans", African and Asian Studies, 6 (3): 230.
} 
Indonesia/Malaysia. India provided over $25 \%$ while Madagascar also served as an important source of manpower with a similar percentage. The remainder would have been bought along the East African coast, including Zanzibar. ${ }^{4}$

On a much smaller scale, inter-colonial networks also served to find a place of exile for individuals who were banished because they were considered troublesome. Best known are the Javanese princes and the Islamic leaders from the Indonesian archipelago who were banished to the Cape of Good Hope, such as Sheikh Yusuf of Macassar. Banishment very occasionally also occurred from the Dutch possessions on the Gold Coast, with examples of men and women being deported to Surinam and in one instance to the Dutch East Indies.

\section{Indentured Labour}

After the abolition of the trans-Atlantic slave trade, and more specifically after the abolition of slavery itself, indentured Asian labour became an important means of meeting global labour demands, with India and China providing the most important pools of manpower. Although indentured labour is usually associated with Asia, certain recruiting practices in $19^{\text {th }}$ century West Africa arguably fall into the same category. In the Dutch colonial world, labour problems in Surinam after the abolition of slavery in 1863 were addressed by recruiting indentured labour from India and, in much smaller numbers, from China and Java. China also became an important source of manpower for the plantations of Sumatra. At the beginning of the $20^{\text {th }}$ century, some 100,0000 coolies worked on Sumatra's East Coast. ${ }^{5}$

In the 1860s, a Dutch governor in Elmina, the Dutch headquarters on the Gold Coast, contemplated the importation of Chinese workers for plantation labour, because local Africans were not willing to work on plantations. ${ }^{6}$ Nothing came of it, but the British did later experiment with bringing Chinese mineworkers to the Gold Coast. In discussing the "native labour question", British colonial officials expressed a firm belief

\footnotetext{
${ }^{4}$ Robert Shell (1994) Children of Bondage: a Social History of the Slave Society at the Cape of Good Hope 1652-1834, Johannesburg: 40-42.

${ }^{5}$ J. Breman (1989) Taming the Coolie Beast: Plantation Society and the Colonial Order in Southeast Asia, Delhi: 2.

${ }^{6}$ Nationaal Archief, The Hague (hereafter NA), Verslag wegens de overdragt aan Engeland van de Nederlandsche Bezittingen ter Kuste van Guinea. Kamerstukken zitting 1873-1874.
} 
in the superiority of Chinese over African labour. The Chinese were depicted as hardworking, disciplined and productive, while Africans were seen as racially inferior: unskilled, indolent and unproductive. ${ }^{7}$ For military purposes, racial stereotyping was precisely the opposite: Chinese were considered unfit for army service, while Africans were cast as "martial races".

On the Gold Coast, experiments with Chinese mineworkers in 1897 and again between 1902 and 1914 proved unsuccessful. While the mining projects on the Gold Coast involved only small numbers of Chinese - dozens rather than hundreds - the goldmines of the Transvaal under British rule employed no less than 60,000 Chinese indentured labourers in the early $20^{\text {th }}$ century. ${ }^{8}$ This venture was ultimately abolished due to the resistance of white labour, but an earlier scheme of importing indentured labour from India for the sugar plantations of Natal had much more lasting effects. The recruitment of over 150,000 indentured plantation workers from India between 1860 and 1911 resulted in the permanent presence of a substantial population of Indian South Africans.

\section{African Labour in the Dutch East Indies}

While both the Atlantic slave trade and the massive recruitment of indentured labourers from India and China have received ample scholarly attention, much less is known about the experiences of Africans who were brought to Asia, forcibly or voluntarily. ${ }^{9}$ This paper explores a largely unknown aspect of inter-colonial labour migration: the use of African labour in the Netherlands East Indies. My own research has focused on the recruitment of African soldiers for the Dutch colonial army in the mid-19 ${ }^{\text {th }}$ century. These 3,080 men from the Gold Coast and its hinterland were no doubt the best documented and possibly the largest group of African immigrants, but they were by no means the first Africans to arrive in the Indonesian archipelago. I will first give a brief survey of the use of African labour in the age of slavery, based on secondary sources.

\footnotetext{
${ }^{7}$ K. Akurang-Parry (2001) "We Cast about for a Remedy: the Opposition of the Gold Coast Press to the Chinese Mine Labour Experiment in the Gold Coast, ca. 1874-1914", The International Journal of African Historical Studies, 34 (2): 372.

${ }^{8}$ P. Richardson (1984) “Chinese Indentured Labor in the Transvaal Gold Mining Industry, 1904-1910”, in K. Saunders (ed.) Indentured Labor in the British Empire 1834-1920, London: 260-90.

${ }^{9}$ I. van Sertima (1985) The African presence in early Asia, New Brunswick, N.J.; S. de Silva Jayasuriya \& R. Pankhurst (eds.) (2003) The African Diaspora in the Indian Ocean, Trenton, N.J.; S. de Silva Jayasuriya \& J-P. Angenot (eds.) (2006) "The African Diaspora in Asia: historical gleanings", African and Asian Studies, 5 (3/4): 217-397; K. K. Prasad \& J-P. Angenot (eds.) (2008) TADIA: The African Diaspora in Asia, Bangalore.
} 
My account of the recruitment of African soldiers in the age of indentured labour is based on my own research in the Dutch archives as well as interviews.

Although Java was much more densely populated than the Cape of Good Hope, the VOC nevertheless needed to import slaves to meet its labour needs. Slave imports into Batavia alone reached about 1,000 annually in the $17^{\text {th }}$ century and rose to about 3,000 per year in the $1770 \mathrm{~s} .{ }^{10}$ Most came from other Indonesian Islands, from the Malabar and Coromandel Coast, or from elsewhere in Asia. Slavery was an indigenous institution in the archipelago, and the use of slaves as soldiers was common practice. For its slave battalions, the VOC recruited initially from Bali and Makassar and later from Bengal and Madagascar. ${ }^{11}$ Even after the age of company rule, the East Indies army used involuntary labour on a massive scale. Governor Daendels (1808-1811) recruited from former company slaves and bought slaves from Dutch residents, as well as imposing a levy on local Javanese rulers, who were obliged to deliver one soldier per 1,000 inhabitants. ${ }^{12}$ In the course of the $19^{\text {th }}$ century, the East Indies army came to rely heavily on convict labour for porter duties and other physically demanding work. When the Dutch abolished slavery in the East Indies in 1859, forced labour already exceeded slave labour. During the last quarter of the $19^{\text {th }}$ century, the use of forced labour by the East Indies army showed a marked increase. ${ }^{13}$ In the colonial context in the $19^{\text {th }}$ century, various forms of unfree labour were the rule rather than the exception.

For the $17^{\text {th }}$ century, we have several instances where reference is made to importing labour from Africa to the Indonesian archipelago. Already in 1615, Governor-General Gerard Reynst remarked on the superiority of slaves over Dutch labourers: "I have already discovered that one slave accomplishes more work than two or more of our own people could do". ${ }^{14}$ In 1626, the VOC for the first time sent a vessel to Madagascar to

\footnotetext{
${ }^{10}$ J.C. Armstrong \& N.A. Worden (1988) "The Slaves, 1652-1834”, in R. Elphick \& H. Giliomee (eds.) The Shaping of South African Society 1652-1840, Middletown, Conn.: 110.

${ }^{11}$ Gedenkboek KNIL (1961), uitgegeven in opdracht van de Vereniging van Oud-Onderofficieren van het Koninklijk Nederlands-Indisch Leger Madjoe, ter gelegenheid van haar 50-jarig bestaan, s. $1: 41$.

${ }^{12}$ S. Kalff (1929) "Inlanders en Afrikanen in het O.I. leger”, Indisch Militair Tijdschrift 51: 782.

${ }^{13}$ G.J. Knaap (1995) "Slavery and the Dutch in Southeast Asia", in G. Oostindie (ed.) Fifty Years Later: Antislavery, Capitalism and Modernity in the Dutch Orbit, Leiden: 202.

${ }^{14}$ Y. Ranjeva-Rabetafika, R. Baesjou \& N. Everts (2000) "Of Paper and Men: A Note on the Archives of the VOC as a Source for the History of Madagascar”, Itinerario 24 (1): 48.
} 
explore whether slaves from there might be of use in Batavia. ${ }^{15}$ For many centuries, Madagascar had provided slaves to the Middle East. From the 17th century onwards, European merchant ships began to follow the example of Arab traders in tapping the Malagasy slave markets. This first Dutch voyage with Malagasy slaves was not a successful venture. The voyage to Batavia was too long, too many slaves perished on the way and slaves from Madagascar were more expensive than those from Bengal and the Coromandel Coast.

By way of experiment, in 1658 the VOC sent two Indiamen to the West African coast to buy slaves. As this was within the traditional realm of the triangular trade conducted by the Dutch West India Company (WIC), the WIC complained about an infringement on its monopoly. Both shiploads were delivered at the Cape of Good Hope. The ship De Rode Vos delivered 228 slaves from Dahomey. Another shipload of 174 slaves, chiefly children, was the result of a chance capture by the Dutch of a Portuguese slaver with Angolan slaves bound for Brazil. Some of these 402 slaves were sent on to Batavia. ${ }^{16}$ Except for perhaps a few individuals, these two shiploads of Angolan and Dahomean slaves were the only West African slaves brought to the Cape in the VOC period. On the East Coast, Madagascar and Mozambique served as the VOC's main source of slaves for the Cape and Mauritius, but a small surplus of slaves could sometimes be taken to Batavia.

In 1671, the VOC started mining gold at Sillida (now Painan, near Padang) in Sumatra. Initially European workers were used but, due to the harsh conditions and malaria, mortality was extremely high. Batavia desperately required forced labour. Bengal slaves were no longer available. Men from New Guinea, Borneo, Nias or Bali were thought too weak for this hard labour. Malabar was short of slaves, and these were also believed to be too weak for the goldmines. Madagascar remained the only option. Slaves from Madagascar were "strong, robust and rudely built" ("grof van leedenen") and could be used for heavy work. From the early 18th century, they were also brought to Ceylon while the British East India Company used them for the pepper plantations on Sumatra's Bencoolen coast. Slaves destined for the mines mostly sailed directly from

\footnotetext{
${ }^{15}$ R. Barendse (2002) The Arabian Seas: the Indian Ocean World of the Seventeenth Century, Armouk N.Y.: 261.

${ }^{16}$ Armstrong \& Worden (1988: 111).
} 
Madagascar to Padang, but smaller numbers of Malagasy slaves landed in Batavia, where they were mainly used as bodyguards, construction workers or "bullies" assistants to the bailiff. For household duties, Balinese slaves were preferred; they were not only more suitable and delicate, but also cheaper.

According to Barendse, Malagasy slaves were rarely sold to individuals, being used instead as chattel slaves by the VOC. In both Batavia and Bencoolen, the Malagasy slaves formed a separate community. There is no evidence of a flourishing community of Malagasy freemen in Batavia, although there were a few at Bencoolen. It would seem that the Malagasy slaves have left no trace in the Dutch East Indies. The sources indicate that their lives were indeed short and brutal, with little or no opportunity to establish a family life. Malagasy slaves were notorious for jumping overboard on the high seas or starving themselves to death. Batavia issued orders that only young men between the ages of 16 and 24 ought to be bought, because elder men "bereft of kind, kin and fatherland, and fetched away in bondage for all eternity, when remembering their past life, immediately start to mourn, and die". ${ }^{17}$ Occasionally, some women and children were purchased as well, because the chiefs on Madagascar were not willing to sell young men only. Women were considered useful for cooking and breeding purposes. Barendse doubts whether the returns of the Sillida mines were worth the considerable expense of the Madagascar trade.

The trade in Malagasy slaves to the East Indies seems to have peaked in the last quarter of the $17^{\text {th }}$ century. The high mortality rate among the slaves on board ship led to a new scheme to reduce losses. Malagasy slaves were first brought to the Cape for recovery purposes and then would be sent on to the East on the next company ship. In 1684, Governor-General Camphuys perceived an additional benefit of this new route: during the voyage, some men could easily be trained as crew members since they came from a nation of good sailors. ${ }^{18}$

The VOC trade in Malagasy slaves continued in the $18^{\text {th }}$ century, but for the most part only to the Cape of Good Hope. I have found hardly any references in the literature about African slaves brought to the East Indies during the $18^{\text {th }}$ century. VOC officials

\footnotetext{
${ }^{17}$ Barendse (2002: 270).

${ }^{18}$ Ranjeva-Rabetafika, Baesjou \& Everts (2000: 50).
} 
also engaged in private trading, and it is quite conceivable that company servants purchased individual slaves in Africa either for personal use or for sale in Batavia, but these transactions would not appear in VOC documents.

\section{Conquest, Control and Coercion}

The most intriguing occupation mentioned for African slaves in the $18^{\text {th }}$ century is the duty of assistants to the bailiff. In every colonial empire, the jobs of conquest, control and coercion posed particular problems. These duties were often performed by outsiders, men who would not be tempted to make common cause with the colonial subjects and who inspired fear in the local population. Thus the VOC employed visible foreigners to apprehend fugitives and administer physical punishments. Both at the Cape and in the East Indies, these servants of justice were called Kaffirs. At the Cape, they were eastern slaves or convicts who functioned as auxiliary police to apprehend escaped slaves and to act as disciplinarians. Punishments, whether judicial or not, were usually administered to slaves and sometimes to Europeans by these "servants of justice". On this account the Kaffirs were hated and feared by the slaves, and indeed by some whites. It is noteworthy that at the Cape this function was performed by Asians; at Batavia the Kaffirs were African slaves. ${ }^{19}$

Very little is known about this use of African labour, although the practice apparently continued for some two centuries, at least until the end of VOC rule. I have found only a few references to it, relating to the $17^{\text {th }}$ and the $18^{\text {th }}$ century. In an entertaining historical drama about a stormy marriage in high colonial society in $17^{\text {th }}$ century Batavia, Leonard Blussé mentions in a footnote that the suspects were arrested by the constable with his eight "Kaffirs", Africans from Mozambique or Angola. ${ }^{20}$ In a broad historical overview, F. de Haan discusses the organisation of policing and justice under VOC rule. The bailiff, a VOC official, was assisted by neighbourhood watchmen (wijckmeesters), a European substitute and four dieffleijders or Kaffirs in red uniforms. Initially, the Kaffirs were Africans from Angola or Mozambique, whose brute force was considered a qualification for the job of police assistant or assistant-executioner. Later, the number

\footnotetext{
${ }^{19}$ Armstrong \& Worden (1988: 128).

${ }^{20}$ L. Blussé (1997) Bitters bruid: een koloniaal huwelijksdrama in de gouden eeuw, Amsterdam: 170, fn. 189.
} 
of Kaffirs expanded to 44 and included indigenous Indonesians whose job description remained "Kaffir". 21

Presumably it was this experience with the Kaffirs as law enforcers that inspired the experiment with African soldiers for the Dutch East Indies army. In 1831, the commander in chief of the Dutch East Indies army in 1831 reacted favourably to a proposal from The Hague to recruit Africans for the Dutch colonial army or KNIL (Koninklijk Nederlandsch-Indisch Leger), Major General De Stuers had had personal experience with African police auxiliaries. He was convinced that Africans would be able to withstand the climate and the strenuous army campaigns and that they would serve loyally, provided that they were well treated and that proper discipline was maintained.

It is beyond doubt that the Negro instils great fear in the natives, and that he is unlikely to fraternise with the natives. As an example, the undersigned can state that he personally experienced during his stay as military commander and civil administrator on Sumatra's West Coast how the Africans among the police auxiliaries caused great alarm. Therefore Africans were favoured for policing duties. ${ }^{22}$

\section{The Paradox of Colonial Armies}

Enlisting Africans in colonial armies was, of course, common practice during the $19^{\text {th }}$ and $20^{\text {th }}$ centuries. Like the Africans in the Dutch East Indies army, the Tirailleurs Sénégalais, established in 1857, were largely of servile descent. However, the practice of enlisting Africans for French military service is much older and goes back to $17^{\text {th }}$ century Senegambia. ${ }^{23}$ African soldiers were not only instrumental in the wars of conquest and the consolidation of colonial rule in Africa, but were also used for military expeditions overseas. Troops from North Africa and West Africa formed a substantial part of the French army in the two World Wars. The use of West African troops as part of the French occupation forces in the German Rhineland after the Allied victory in

\footnotetext{
${ }^{21}$ F. de Haan (1922-23) Oud-Batavia, gedenkboek uitgegeven door het Bataviaasch Genootschap van Kunsten en Wetenschappen naar aanleiding van het driehonderdjarig bestaan der stad in 1919, drie delen. Batavia: vol. I, 292; vol. II 305-36.

${ }^{22}$ NA, Algemene Staatssecretarie en Kabinet des Konings 1813-1814, inv. no. 5743, Nota van De Stuers, exh. 1 Juni 1831 , no. 75.

${ }^{23}$ M. Echenberg (1991) Colonial Conscripts: The Tiralleurs Sénégalais in French West Africa, 18571960, Portsmouth NH.
} 
World War I inspired local resentment and racist propaganda in Germany. ${ }^{24}$ Africans were the ultimate strangers, both in the European context as well as in the Asian colonial world. The French used African troops in their wars in Indo-China in the 1950s, while the British deployed their Gold Coast regiments in the Burma campaign of World War II.

In all cases, the rationale for African recruitment was similar: a shortage of European troops and high mortality rates among European soldiers in the tropics. Lower costs could have been an argument, but there were obvious limitations to cost cutting. In order to secure the loyalty of the African troops, they were often granted special benefits and privileges, which also served to enhance their status vis-à-vis civilian society. Thus, African troops from different ethnic backgrounds, and often of servile origins, acquired a sense of superiority over the civilian colonial subjects, as well as a new corporate identity. Particularly when serving far away from home, the army became a substitute family, to which soldiers could be tied by strong bonds of loyalty. ${ }^{25}$

The Dutch East Indies army also employed indigenous soldiers from the Indonesian archipelago. After the first phase of colonial conquest, it was feasible to recruit local troops for army and policing duties, but every colonial ruler entertained worries about the loyalty of indigenous troops. It was imperative to prevent fraternisation with the locals and to promote identification with the army. Throughout the $19^{\text {th }}$ century, the Dutch East Indies army operated on the principle that roughly one half of the troops ought to consist of Europeans. However, the numbers of volunteers in the Netherlands always fell short of the manpower required. Mortality in the tropics was high and the status of colonial soldiers was very low. Conscription had been introduced for the national army, but enlistment for the colonial army was on a voluntary basis. As more and more European countries introduced conscription, it became more difficult to hire mercenary soldiers. After the secession of Belgium -an important source of manpowerin 1831, most mercenary soldiers came from Switzerland and Germany. From 1820, the Dutch government began exploring alternative recruitment strategies.

\footnotetext{
${ }^{24}$ G. Mann (2006) Native Sons: West African Veterans and France in the Twentieth Century, Durham/London: 17.

${ }^{25}$ T.H. Parsons (1999) The African Rank and File: Social Implications of Colonial Military Service in the King's African Rifles, 1902-1964, Portsmouth, New Haven.
} 
The East Indies were the only profitable part of the Dutch overseas empire in the $19^{\text {th }}$ century. At the beginning of the century, Dutch rule was limited to Java, some coastal regions of southern Sumatra, the Moluccan islands and some footholds on the other islands. By 1900, colonial rule had been consolidated throughout the Indonesian archipelago. African soldiers played a part in this process of imperial expansion. African companies fought in Dutch campaigns in Southwest Sumatra, Borneo (Kalimantan), Celebes (Sulawesi), Bali, Timor and the protracted Atjeh (Aceh) war. The Java War (1825-1830) highlighted the dilemmas of the colonial army: the loyalty of local troops could not be taken for granted and losses among the European troops were heavy, with some 8,000 dead. Some of the rebels fled to southern Sumatra, which became the next terrain for army expeditions. The paradox of military labour in colonial armies was obvious. Soldiers were trained to fight, provided with arms but low in status: how to secure their loyalty? How to prevent fraternisation with the local population?

In opting to experiment with African soldiers, the Dutch government was inspired by the example of the British West India regiments. Formed in 1795 to repress slave revolts in the Caribbean, the West India regiments initially consisted of slaves who were preferably bought on the Guinea Coast or the Congo. After the British abolition of the Atlantic slave trade, new recruits were found among liberated slaves delivered by British naval ships to Sierra Leone. Between 1808 and 1833 the British colonial army enlisted about 3,147 liberated slaves. They received the same uniforms and the same pay as white soldiers in these regiments, but while whites served a seven-year contract, for black soldiers the army was a lifetime occupation. As part of their training, it was impressed on the African soldiers that as servants of the British king their status was way above that of the slave population. ${ }^{26}$

Dutch officials based in Surinam and the Dutch West Indies had had the opportunity to see the West India regiments in action. They reported most favourably about the professional performance of these soldiers and their loyalty to the regiment. The West India regiments were also used by the British in their wars against the Ashanti. The locally recruited Gold Coast corps proved useful for policing duties, but totally ineffective in a war against such a powerful opponent. After the Indian Mutiny of 1857- 
1858, Major A.B. Ellis, who had served with the West India regiments, proposed their deployment in India.

For service in India, Negroes seem the very thing; they are sure not to fraternise with the natives. By and by, unless we first lose our Colonial Empire, we shall practically recognise the wisdom of the Romans, who garrisoned each province with troops from a distance. ${ }^{27}$

This particular proposal was not implemented, but the same logic underpinned the recruitment strategies of many colonial and imperial armies. Ellis' argument was quoted in the Dutch colonial press in support of a plea for the recruitment of Africans for the Dutch East Indies army.

The recommendations made by Major Charles Hamilton Smith, who had served 12 years with the British West India regiments, were also influential. Hamilton Smith (born as Karel de Smet, near Antwerp) was a personal acquaintance of the Dutch royal family who held him in high esteem because of his services to the Dutch army in the 1815 campaign against Napoleon. Hamilton Smith praised the strength, discipline, courage and endurance of African troops and emphasised the crucial importance of equal treatment of black and white troops. Provided that they were treated properly and humanely, African troops would serve loyally. Hamilton Smith saw no danger whatsoever of fraternisation between Africans and Asians, as he believed that Asians regarded Africans as cannibals. He thought it advisable to send also a number of black women in order to establish small African communities around Batavia, which would serve to reproduce new manpower for the army. He noted that half rations of rum would be sufficient but that it was absolutely vital to allow them to dance at night, "because all of Africa dances at night". ${ }^{28}$ Hamilton Smith believed that volunteers could be found among free blacks and slaves in Surinam and the Dutch West Indies, but these colonies were already suffering an acute shortage of manpower due to the abolition of the slave trade. After further exploration, the Dutch government turned to its almost forgotten possessions on the coast of Guinea, whose commercial activity had all but halted since the abolition of the slave trade.

\footnotetext{
${ }^{26}$ R.N. Buckley (1979) Slaves in Red Coats: the British West India Regiments 1795-1815, New Haven.

${ }^{27}$ A.B. Ellis quoted in "Iets over de militaire politiek in Indië", Indische Gids (1886) 1: 611-17.

${ }^{28}$ NA, Ministerie van Koloniën voor 1850 (Department of Colonies before 1850, hereafter MK I), Hamilton Smith to Dept. of Colonies, exh. 7 mei 1828 no. 78.
} 


\section{The Beginning of African Recruitment}

Recruitment in St. George d'Elmina, where the Dutch maintained a small presence, began in 1831. Governor F. Last received orders from The Hague to assemble a detachment of 150 "Negro soldiers" for Java. If the experiment proved successful, African recruitment would be expanded to some 2,000 men. Last was under strict instructions to enlist volunteers only, without resorting to coercion. In the East Indies, the African soldiers would be paid and treated on an equal basis with European troops. After the expiry of their 6-year contract, they had a choice between re-enlistment, repatriation to Elmina or settling on Java. In 1831 and 1832, three ships were sent from the Netherlands to Elmina to transport the 150 African troops to Batavia but, in spite of sustained efforts, Last had managed to recruit only 44 men. Some had previously served with the Dutch in the small Elmina garrison, but most were debtors or pawns in debt arrangements who wanted the money to pay off their debts. Some were slaves, who transferred part of their pay to their masters in Elmina or other coastal towns. Some were free men who delegated part of their pay to their parents or other relatives. Although The Hague had expressed a preference for "pure" and unspoilt Africans, this first detachment of 44 men included a number of mulattos who had been handpicked as interpreters, because they knew some basic Dutch.

The small number of men rendered the cost of this experiment excessive. Reports about their military qualities, however, were quite favourable. The first campaigns to include African soldiers were the expeditions to Lampong (Southern Sumatra) and Jambi (central Sumatra) and the Padri War on the West Coast of Sumatra, a protracted revolt by Islamic leaders whose religious fervour had been aroused by a pilgrimage to Mecca. Lieutenant-Colonel H.M Lange led the attack on the Padri stronghold of Bondjol in December 1836. Lange later judged it a mistake to have used the inexperienced Africans in this attack. Although they had already demonstrated the necessary courage, they lacked caution and discipline. Communication problems and unfulfilled promises caused serious troubles and misunderstandings, but in the long term the Africans proved most useful as soldiers. Lange noted that after initial problems, "the African companies excelled in discipline, cleanliness, modesty and order. Dutch officers considered posting with the African companies as a favour". 29

\footnotetext{
${ }^{29}$ H.M. Lange (1852) Het Nederlandsch Oost-Indisch Leger ter Westkust van Sumatra (1819-1845), 's Hertogenbosch: 161, 172-74.
} 


\section{Mission to Kumasi}

Meanwhile, African recruitment on the Guinea Coast had resumed on a much more ambitious scale. In 1836, King Willem I sent Major-General Jan Verveer as envoy to the Ashanti court. So far recruitment along the Coast had yielded only a trickle of volunteers, causing Governor Lans to resort to buying slaves and enlisting them for periods of up to 20 years. Since these slaves had not been manumitted, this type of recruitment amounted to a violation of the international treaties banning the slave trade.

On his arrival in Elmina, Verveer immediately ended this practice. Lans, now living in retirement in the Netherlands, was severely censored and his recruits were retroactively manumitted. The British, who policed the ban on the transatlantic slave trade, had strongly objected to Lans' recruitment methods, but initially raised no objections against Verveers' scheme, once he had ensured that only free men or manumitted slaves would be enrolled. ${ }^{30}$

In the new, expanded recruitment scheme the focus was on the Kingdom of Ashanti, an old ally of Elmina and the Dutch. In the past, Ashanti had been a major supplier of slaves. The Dutch believed that Ashanti still commanded a surplus of manpower, some which surely could be made available to the Dutch colonial army. After long delays and the exchange of lavish gifts, the contract between King Willem I of the Netherlands and Kwaku Dua I of Ashanti was duly signed in the Ashanti capital Kumasi on 18 March 1837. The contract stipulated that the Ashanti king would deliver 1,000 able-bodied men within a year, in exchange for 6,000 guns with powder. In addition, Verveer obtained permission to open a recruitment bureau in Kumasi, where individuals could enlist. The African soldiers would be entitled to equal pay and equal treatment, in every respect, with European troops. ${ }^{31}$ One exception to this rule, however, was their term of service. While Europeans generally enlisted for six years, the Africans who entered Dutch army service after 1837 were contracted for a period of 15 years or an indeterminate period. The latter applied to slaves from the distant lands beyond Ashanti: the Dutch undertook to provide free passage home for retired soldiers to Elmina, but it

\footnotetext{
${ }^{30}$ NA, MK I, Geheime Verbalen, inv. no. 4243, exh. 6 Dec. 1836 no. 292, correspondence by the British envoy in The Hague, Disbrowe, to the Netherlands Department of Foreign Affairs; MK I, Openbare Verbalen, inv. no. 1076, exh. 11 Feb. 1837 no 24, ibid.; MK I, Geheime Verbalen, inv. no. 4257, no. 410, 28 Dec. 1839, Dept. of Colonies to the Governor-General of the Dutch East Indies.

${ }^{31}$ NA, MK I, Openbare Verbalen, inv. no 1223, exh. 16 April 1839 no. 20, report by Verveer to the Dept. of Colonies; MK I, Geheime Verbalen, inv. no 4246, Treaty between Jan Verveer on behalf of the Dutch King and Kwaku Dua, 18 March 1837.
} 
was inconceivable that the home-bound trip could be extended into the area of presentday Burkina Faso or Northern Nigeria. Although this was never clearly spelt out, these men were considered lifetime soldiers. In 1844, the indeterminate period of service was converted to 15 years.

After expiry of their contracts, the soldiers could opt for re-enlistment, repatriation to Elmina or permanent residence on Java. In the first phase of African recruitment, most chose to return to their native lands. Men from the coastal areas usually returned to their former place of residence, while those from northern regions generally opted to settle in Elmina, where the pensions were paid out. Veterans were allocated plots of land on a hill just behind the Castle of St. George. From the 1840s, this hill became known as Java Hill. Although the name is still in use today, very few present-day inhabitants are familiar with the historical background of Java Hill. I have been able to locate only one descendant of returned KNIL veterans on Java Hill. ${ }^{32}$

As the numbers of Africans in the East Indies increased, veterans increasingly decided to settle with their Indo-African families in the garrison towns on Java, often maintaining close contact with fellow Africans. Particularly for ex-slaves, settlement on Java could be the more attractive option. On the Gold Coast, they would be regarded as former slaves, while on Java they were entitled to European status. Soldiers had a very lowly position in colonial society but, on the other hand, Europeans were considered superior to the native population. Most African soldiers, however, never faced this choice: they died during their long periods of army service. Few actually died on the battlefield. Like Europeans, most Africans succumbed to disease.

On the invitation of King Willem I, the Ashanti king entrusted his young son and his nephew to Verveer, to be taken to the Netherlands for a European education. The nephew, Kwamena Poku, later returned to Elmina as an army corporal. His intention had been to return to Kumasi, but he had become alienated from the land of his birth. No longer able to speak his native Twi, he wasted away in Elmina and ultimately

\footnotetext{
${ }^{32}$ The one exception is the Witts family, descendants of soldier Jan Wit, who returned to Elmina in 1880 after 12 years of army service. He left his son Melchior behind on Java. Jan Wit began a new family life in Elmina, while young Melchior joined the Dutch army. The descendants of Melchior Wit now live in the Netherlands. I did meet other Ghanaian descendants of KNIL soldiers, notably the descendants of corporal Manus Ulzen, who was among the first volunteers to enlist in 1832. The Ulzen family, however, was no longer living in Elmina, although they maintained strong bonds with their place of origin.
} 
committed suicide on 22 February 1850. The son, Kwasi Boakye, studied to become a mining engineer and eventually died of old age on Java. ${ }^{33}$

The Ashanti had a great reputation as a warrior nation and Verveer had initially hoped to enlist them for the Dutch army, but it soon became apparent that this was out of the question. In practice, the troops recruited in Kumasi were slaves captured by the Ashanti in war, rendered as tribute or bought at slave markets such as Salaga. They came from north of Ashanti, perhaps even as far as the bend of the Niger River. They were generically known as Donkos. Enlisting free Africans as volunteers proved a pipe dream. In order to reconcile the recruitment effort with the obligations of the treaties banning the slave trade, the recruits were issued with an Act of Manumission. They purchased their freedom with an advance on their army pay of about 100 guilders, to be repaid over the years by deducing 8.5 cents a day from their pay. Verveer reckoned that the soldiers would be able to pay off their debts in two years, after which they would enjoy equal status in every respect with the European soldiers. ${ }^{34}$

The first batch of African soldiers was registered using their own names transcribed into Dutch. With increasing numbers, this became a source of confusion since men were often named after their day of birth and so many of the names were the same. Moreover, Dutch officers found it difficult to pronounce and remember African names. Verveer therefore decided that the recruits from the interior should be given Dutch names, preferably of a short monosyllabic kind. ${ }^{35}$ In daily roll-calls on the troop ships, the Africans had to memorise their new Dutch names: Klink, Baas, Land, Prins, Nelk, Beelt, Hoed, Herbig, Pop, Cordus, Stap, IJs, etc.

The Ashanti ruler, Asantehene Kwaku Dua, proved negligent in fulfilling the obligations in the treaty. When recruitment ended in 1842, he had delivered only 235

\footnotetext{
33 For the story of the two Ashanti princes, see L.W. Yarak (1987) "Kwasi Boakye and Kwame Poku: Dutch-educated Asante 'Princes'”, in E. Schildkrout (ed.) The Golden Stool: Studies of the Asante Center and Periphery, New York. The story has acquired international fame after the publication of a historical novel by Dutch author, Arthur Japin, which has also been published in English translation.

${ }^{34}$ NA, MK I, Openbare Verbalen, inv. no 1223, exh. 16 April 1839 no 20, report by Verveer to the Dept. of Colonies.

${ }^{35}$ NA, MK I, Geheime Verbalen, inv. no 1393, exh. 22 Sept. 1841, no. 39/479, Verveer to the GovernorGeneral of the Dutch East Indies.
} 
men. ${ }^{36}$ Numerous recruits sent by the king were returned to Kumasi because they were too young, too old or not in good health. Instead, most African recruits were obtained from the recruitment agency in Kumasi, which was staffed by a Eurafrican official in Dutch service, Jacob Huydecooper. Recruitment also continued along the Coast. By 1842, some 2,200 men had been sent from Elmina to Batavia. The procedure prescribed by Verveer required that all recruits be asked explicitly and individually whether they voluntarily accepted to enlist. In quite a few cases, the Dutch governor concluded that the men had been brought against their own will. They were sent away or returned to their owner. ${ }^{37}$ As long as the proper procedures were adhered to, the recruits did have a certain choice in the matter, even though the choice was limited to remaining a slave or becoming soldier. Not content with this limited choice, quite a few recruits attempted desertion, but this was rarely successful. Some governors were undoubtedly more lax than others, but judging from the Elmina journals after 1837, it was fairly routine procedure to inquire whether the recruits consented, although this probably could not have applied to the recruits sent from Kumasi. Substantial numbers of men were turned back because of physical or mental deficiencies or advanced age. Some begged not to be sent back to Kumasi, fearing dire consequences.

In 1840, a shipment of 50 recruits destined for Surinam to supplement the Corps Colonial Guides caused alarm in London. As this transport followed the traditional route of the slave trade, it was much more sensitive than the recruitment for the East Indies. The British foreign minister, Lord Palmerston, wrote to The Hague, objecting to this "pure and simple act of slave trading". ${ }^{38}$ In 1841, King Willem I decided to end recruitment in Africa, but this was more in response to panicky army reports from the East Indies in the wake of a series of African mutinies than in reaction to British protests. African recruitment was reopened in 1855 , but on a more modest scale.

\footnotetext{
${ }^{36}$ NA, MK I, Ingekomen stukken van de Kust van Guinea, inv. no. 4012, Governor Van der Eb to Dept. of Colonies, 31 Oct. 1842.

${ }^{37}$ These cases are mentioned in the journals kept by the Governor in Elmina: NA, MK I, Journalen van de Kust van Guinea, inv. no 3964-3975. For a detailed discussion on the issue of voluntary or forced enlistment, see L.W. Yarak (1996) "New Sources for the Study of Akan Slavery and Slave Trade: Dutch Military Recruitment in the Gold Coast and Asante, 1831-72" in R. Law (ed.) Source Material for Studying the Slave Trade and the African Diaspora: Papers from a conference of the Centre of Commonwealth Studies, Stirling. For the places of origin of the men recruited in Kumasi, see J.R. LaTorre (1976) "Birthplaces of Dutch East Indies Troops 'recruited' in Kumase, 1837-1842", Asante Seminar 1976, no. 5: 31-42.

${ }^{38}$ NA, MK I, "Suriname na 1828”, inv. no. 49. Correspondence with the British Commissioners relating to the Slave Trade, p. 241, Palmerston to Disbrowe, 10 Sept. 1840.
} 
In discussing whether this recruitment effort indeed amounted to covert slave trading, the American historian, Larry Yarak, concludes that the practice in effect fits $19^{\text {th }}$ century patterns of indentured labour. The African soldiers served a contract of limited duration, after which they were free to settle on Java or return to the Gold Coast. Indeed hundreds of veterans did return to Elmina, often with pensions. The issue of whether the Africans actually enlisted voluntarily is more complicated, but the available evidence indicates that in most cases they had a certain say in the matter. However, the situation on the Gold Coast was a far cry from the prevailing images in the Netherlands. Dutch policy makers believed that Africans lived in abject poverty, suffering the oppressive rule of brutal tyrants. Therefore, they would be only too happy to enlist as soldiers in the service of a benign and enlightened government. This proved a serious miscalculation: free Africans saw no reason to leave the land of their birth, only slaves could conceivably consider this option as a way of obtaining their manumission.

Rather than a revival of the export slave trade, Yarak concludes, this recruitment effort for the Dutch East Indies army should be seen as “a distinctly 'modern' form of labour recruitment in which a far greater number of men willingly participated than has previously been thought". ${ }^{39}$ In some respects, the African soldiers in Java were better off than Asian indentured labour in the Western hemisphere. In terms of mortality on board ship, an important criterion in distinguishing the transport of indentured workers from the transatlantic slave trade, the African soldiers compare very favourably. Mortality among Indian migrants to the West Indies between 1851 and 1870 was 6.5\%, and among British migrants for New York it was around 1\% in the period 1836-1853. ${ }^{40}$ In comparison, mortality among African recruits during the three-month voyage from Elmina to Batavia was around $0.84 \%{ }^{41}$ In other respects, the fate of the African soldiers was harsher: their period of service was much longer than in the case of most indentured workers, and mortality on the job was higher. Unlike indentured workers, the African soldiers did not enjoy the comfort of sharing their household with women from their region of origin. Like the European soldiers in the East Indies, they lived with

\footnotetext{
${ }^{39}$ Yarak (1996: 53).

${ }^{40}$ D. Northrup (1995) Indentured Labor in the Age of Imperialism, 1834-1922, Cambridge: 89.

${ }^{41}$ The records are not complete. I have made this calculation on the basis of 2,336 records out of a total number of 3,080 soldiers over the period 1831-1872. These records cover 28 ship transports.
} 
indigenous women, which must have facilitated their adaptation to their new environment.

\section{Military Merits}

Since African recruitment had been launched as an experiment, the KNIL had issued instructions that detailed reports be made on both positive and negative experiences with this new source of manpower. Initial army reports on the performance of the Africans were largely favourable, in spite of the numerous communication problems that made their training both difficult and time-consuming. The Africans spoke a variety of African languages, which were often not mutually intelligible. They understood neither Dutch nor Malay, the languages of instruction in the army. A few Eurafricans and Africans could act as interpreters between Dutch and Fanti or Twi (the languages spoken on the Gold Coast and in Ashanti), but there were never sufficient interpreters to serve in all the African companies. Because of the language problem, the Africans were not yet fully subjected to the army's code of discipline. The KNIL command issued instructions for lenient treatment, and therefore their misdemeanours were rarely punished.

According to their commanding officers, the main vice of the Africans was laziness, resulting in uncleanliness. They took better care of their weapons than of their uniforms. The Africans kept their distance from both Europeans and native Indonesians. It was emphasised that they looked down on the native population. The officers remarked that they were very distrustful, always worrying about being cheated. The nature of the Africans was described as "hot-tempered, irascible and often very insolent". Another officer remarked that they were "of a rough nature, jealous, distrustful and greedy". On the other hand, they were honest men. No instances of thievery had been reported. The Africans were strong, muscled, indefatigable and very well adapted to the tropical climate. In battle, they demonstrated bravery and fearlessness, even more so than the Europeans. In combat, their ardour needed to tempered, otherwise they ignored the orders of their officers. Some reports complain about substantial drinking, but alcoholic excesses were less serious than among the European soldiers. ${ }^{42}$ On balance, the

\footnotetext{
${ }^{42}$ NA, Ministerie van Koloniën na 1850 (Department of Colonies after 1850, hereafter MK II), Generaal Overzigt van hetgeen betrekking heeft tot de werving van Afrikanen en van de verkregen resultaten, inv. no 49, exh. 4 Nov. 1850, no. 24, Verslag over bij het leger dienende Afrikanen, 3 Sept. 1838 no. 3 geheim.
} 
judgement was largely positive, certainly in comparison to the bitter complaints that were regularly voiced about drunken, lazy and undisciplined European troops.

The Department of Colonies had proposed to form a separate African corps in the KNIL, to protect the Africans from European vices. Army command in Batavia was, however, strongly opposed to this idea, because the Africans manifested a strong esprit de corps. Too many Negroes in one corps could cause great mischief: they seemed already inclined to mutinies. When banding together in large numbers, the Africans could become ungovernable. It was therefore decided to distribute the African companies over ten battalions. A battalion consisted of six companies, each counting about 100 men. To maintain a balance, the other companies would consist of Europeans, natives or perhaps Amboinese. The Amboinese, being Christians, enjoyed a privileged status in the colonial army, occupying an intermediate position between Europeans and native Indonesians. Exceptionally, two battalions were to have three African companies each, but here the other half would consist of Europeans only. By 1840, the KNIL counted 16 European, 9 African, 17 Amboinese and 40 native companies. ${ }^{43}$

A few reports indicate that some of the Africans suffered from homesickness or had other problems adapting to their new lives. Some were repatriated to Elmina as unsuitable for army service. In July 1838, ten Africans armed with bayonets left the barracks in Surabaya "under the pretext of wanting to return to their native lands". They became involved in a fight with the local population, who were usually eager to apprehend deserters as they were given a reward for every man delivered at the army barracks. When they were returned to the garrison, five of the deserters were injured. ${ }^{44}$

\section{Mutinies $^{45}$}

By and large however, the Africans seem to have adjusted well to their new role, jealously guarding their status as European soldiers. Most discontent was related to

\footnotetext{
${ }^{43}$ NA, MK I, Openbare Verbalen, inv. no 1219, exh. 25 March 1839, no. 16, the Commander-in-chief of the KNIL, General Cochius, to the Governor-General. Also: MK II, Generaal Overzigt, Verslag over bij het leger dienende Afrikanen, 3 sept 1838 no. 3 geheim; Gedenkschrift Koninklijk Nederlandsch-Indisch Leger (1990: 65).

${ }^{44}$ NA, MK I, inv. no. 4551, exh. 10 Dec. 1841 no. 527 geheim, Acting Governor Merkus to Dept. of Colonies.

${ }^{45}$ For a more detailed account of the mutinies, see I. van Kessel (2003) "African mutinies in the Netherlands East Indies: a nineteenth century colonial paradox", in J. Abbink, M. de Bruijn \& K. van Walraven (eds.) Rethinking Resistance: Revolt and Violence in African History, Leiden.
} 
infringements of the promise of equal treatment. Nothing caused more resentment than the belief that they were being treated as natives rather than as Europeans. Widespread discontent broke out in 1838, when the Africans were ordered to exchange their (European) straw mattresses for (native) sleeping mats. A similar measure had previously been ordered for the Amboinese. Unlike the native soldiers, the Amboinese were entitled to wear shoes, an important attribute of European status. Until 1908, the KNIL issued shoes only to European, African, Amboinese and Menadonese soldiers. ${ }^{46}$ Because of this symbolic significance, Amboinese soldiers would never leave the garrison without shoes. But the shoes were very uncomfortable: inside the military quarters the Amboinese often walked barefoot, thus muddying their mattresses. For this reason, the Amboinese were not entitled to socks. The Africans behaved similarly. From 1838, the KNIL stopped issuing socks to the Africans. This did not inspire protest but the sleeping mat proved to be a different matter. The Amboinese, for their part, had accepted the sleeping mats without protest.

Subsequently the measure was extended to the African soldiers, as "they were known to be of an uncleanly nature, to have a greasy skin, greasy hair and a peculiarly strong and unpleasant smell". 47 Coming on top of accumulating grievances about unequal treatment, the issue of the mattresses became the final straw. Other grievances were related to their longer term of service and lower pay, as a result of the deduction of 8.5 cents to repay the costs of manumission. These deductions had become a permanent feature, continuing long after the due amount of about 100 guilders had been repaid. This meant that the Africans were no longer paying off a debt, but that they received structurally lower pay than the Europeans.

In mid-1838, a mutiny erupted among the Africans of the $1^{\text {st }}$ Infantry Battalion at Padang Riboe Riboe, on Sumatra. The mutineers were brought before a military tribunal but the case remained inconclusive because of language problems. Africans who could have served as interpreters were suspect as accomplices to the mutiny. As Acting Governor Merkus later related, this had made it impossible to impose an exemplary punishment, which he had deemed necessary "to reign in the spirit of insubordination

\footnotetext{
${ }^{46}$ C.A. Heshusius (1986) KNIL 1830-1950: een fotodocumentaire over het dagelijks leven van het koloniale leger in Nederlands Indië, Houten: 21.

${ }^{47}$ NA, MK II, Generaal Overzigt, Missive van den kommandant van het observatiekorps, dd. 6 Feb. 1838 no. 186.
} 
that prevailed among these savage people, who seem immune to civilisation". 48 The spirit of rebellion became more widespread in 1840 and 1841. Several instances of armed revolt were reported from Sumatra and central Java. The two African companies in the $4^{\text {th }}$ Battalion at the garrison town of Kedong Kebo (Purworejo) on central Java apparently gained confidence when their numbers were augmented by the formation of a third African company. The commander of the $4^{\text {th }}$ Battalion received reports that the Africans had held a nocturnal gathering where they had sworn an oath that on 16 April 1840 they would demand equal pay with the Europeans. If their demand was not met, they would go on strike. On the agreed day, the Africans of the $3^{\text {rd }}$ and $5^{\text {th }}$ companies disobeyed their officers and returned to their barracks to seize the firearms. The $4^{\text {th }}$ company had already armed itself. However, as the commander had been warned about the nocturnal oath, he had taken precautions. European troops had already occupied the barracks to prevent the Africans from taking the guns. The three European companies dispersed the mutineers, after which armed patrols were sent out in pursuit. They apprehended 85 fugitives, while three men managed to escape. ${ }^{49}$

For the first time, the Africans were court-martialed. The sentences passed by the Supreme Military Tribunal at Semarang on 18 December 1840 were fairly lenient. An investigation ordered by the public prosecutor had established that there was no uniform procedure to acquaint the Africans with the army's code of discipline. Mutiny could carry the death penalty, but it was not certain that the Africans had been aware that their actions amounted to mutiny. In the $4^{\text {th }}$ Battalion, the articles of the disciplinary code had been read to the troops monthly in the Malay language. As a result of their contacts with native women, the Africans were more familiar with Malay than with Dutch. But the officers had never checked whether the African troops indeed understood what constituted a criminal offence and what would be the related punishments. The court therefore judged that the Africans could not be punished with the full severity of military law. The five ringleaders in the Kedong Kebo mutiny were sentenced to two years in prison and 25 strokes. Ten men received 25 strokes and prison sentences

\footnotetext{
${ }^{48}$ NA, MK II, inv. no. 4551, exh. 10 Dec. 1841 no 527 geheim, Acting Governor Merkus to Dept. of Colonies.

49 NA, MK II, Generaal Overzigt, Missive van den militairen kommandant te Kedong Kebo, 17 April 1840 .
} 
ranging from 6 months to one year. The remaining 68 mutineers got off lightly with a prison sentence ranging from two weeks to one month. One African was acquitted. ${ }^{50}$

Army command expected that the court martial would serve as a warning that rebellious behaviour would no longer be tolerated. It is not certain whether the news of the court martial spread to garrisons on other islands. If it did, it did not deter other discontented Africans from staging armed protests. In June 1841, 37 fully armed African soldiers of the $10^{\text {th }}$ Infantry Battalion walked out of the Dutch fortress Van der Capellen on the West Coast of Sumatra, after repeatedly refusing to obey orders. A detachment sent out in pursuit could not persuade the Africans to return to their duties. A fight ensued, leaving two Africans dead and four badly wounded. The remainder were taken prisoner. $^{51}$ The Sumatra revolt was sparked off by the replacement of straw mattresses by native sleeping mats. The mutineers were tried by a military tribunal at Padang and the sentences were confirmed by the Supreme Military Tribunal on 8 April 1842. Two men, Coffie Prins and Kudjo Serroe, were identified as the instigators and sentenced to death. However, the Governor-General exercised his prerogative to commute the verdict to ten years in prison. After serving their prison sentences, Prins and Serroe were dishonourably discharged from the army and shipped back to Elmina. Most others got off lightly, with short prison sentences and/or 25 strokes.

After the Kedong Kebo mutiny, Commander-in-chief General Cochius concluded that the experiment with African recruitment had miscarried. Experience proved that the "Negro race" was not as suitable for the military as had initially been expected. In his opinion, the promise of equal treatment had been a serious psychological error. Negro soldiers would never be a substitute for European troops.

\footnotetext{
${ }^{50}$ NA, MK II, Generaal Overzigt, Missive van den kommandant van het leger, dd. 21 april 1840, no. 12 spoed; Generaal Overzigt, Missive van den Advocaat Fiscaal voor de Land- en Zeemagt, dd. 22 April 1840, no. 171, spoed. Data on the sentences are taken from the individual army records: "Stamboeken onderofficieren en minderen van het Nederlandsch Oostindisch Leger". The records are incomplete, and therefore this account of the sentences might be incomplete as well. The corporal punishment consisted of "klingslagen", strokes with a sword blade.

${ }^{51}$ NA, MK II, Generaal Overzigt, Missive van den militairen kommandant ter Sumatra's Westkust, dd. 9 July 1841 no. 1143/84.
} 
Wherever the Negro soldiers served together in a company, they have banded together in mutiny, under the pretext that infringements had been made on the promise of equal treatment with the European soldier. ${ }^{52}$

In response to Cochius' proposal to halt African recruitment, The Hague instructed Elmina to reduce numbers to 200 soldiers per year, as replacement for Africans who had died or left the army. When news of the Sumatra mutiny reached The Hague, African recruitment was abandoned altogether. ${ }^{53}$

By this point in time, December 1841, the army counted 1,318 Africans. After the initial panic had calmed down, the KNIL command believed that the problem of the "haughty" Africans would solve itself, as they would gradually be phased out from the army. ${ }^{54}$ Throughout the $19^{\text {th }}$ century, the position of the Africans remained ambiguous. In most respects, they were indeed treated as Europeans. But in other respects, such as duration of service, re-enlistment premiums, pensions, and - perhaps most importantly - the continuing deductions which could no longer be justified as restitution of the manumission payment, the KNIL treated the African soldiers as a special category, hovering between Europeans and Amboinese. Full equal treatment was only achieved by the second generation, the Indo-African sons who were born free in the East Indies. Growing up in army barracks, most sons followed their fathers' footsteps in becoming professional soldiers.

Army opinion about the qualities of the African soldiers saw another unexpected twist after the Third Expedition to Bali in 1849. Unlike the two previous expeditions, this third campaign was a military success that was celebrated with much pomp and circumstance on the main square of Batavia. The $7^{\text {th }}$ Infantry Battalion, in which African companies served, had been awarded the highest military honours, the Militaire Willemsorde, the Dutch equivalent of the Victoria Cross. The African troops earned the admiration of several military observers, including the newly arrived commander-inchief of the KNIL, Duke Bernhard van Saksen-Weimar Eisenach, a German aristocrat who had made his career in the Dutch army. He reported to The Hague that the Africans

\footnotetext{
52 NA, MK II, Generaal Overzigt, Missive van de kommandant van het leger, dd. 8 Aug. 1840, no 1 geheim.

${ }^{53}$ Recruitment was ended by Royal Decree, KB 17 Dec. 1841.

${ }^{54}$ NA, MK I, Geheime Verbalen, inv. no. 4294, Cochius to Governor-General 11 Nov. 1842.
} 
compared favourably with the European part of the army below the rank of officer, which mostly consisted of

soldiers with a criminal record, deserters from the Dutch national army, drunkards, deserters from the Belgian and French armies and Germans, most of whom are rascals and tramps, and for whom the service in this colony is a last refuge. ${ }^{55}$

The new commander-in-chief, supported by the new governor in Batavia, urged a resumption of African recruitment. The Dutch government initially declined, but in 1855 recruitment in Elmina was reopened, although on a much more modest scale than before. The new effort had a very slow start. The first detachment left Elmina only in 1860. Recruitment ended with the transfer of the Dutch possessions on the Guinea Coast to Britain in 1872. When the ship Robertus Hendrikus left Elmina on 12 April 1872 with the last batch of 78 soldiers, a little over 800 African recruits had sailed to the East Indies in this second phase of African recruitment. The total number of soldiers from the coast of Guinea in the KNIL adds up to about 3,080. Most of these 800 new troops served in the Atjeh (Aceh) war, the longest and deadliest war in Dutch colonial history.

\section{The Aceh War 1873-1913}

In 1874, two African companies (230 men in total) took part in the second expedition to Aceh. The previous year the first expedition had ended in dismal failure. Mortality during the first phase of the second expedition was very high, largely due to cholera, dysentery and other diseases. The Africans had not been spared. During the first five months, 700 Europeans and 78 Africans succumbed to disease. None of the Africans fell on the battlefield. ${ }^{56}$ During the 40 years of the Aceh War, over 2,000 soldiers Europeans, Africans and native Indonesians - fell on the Dutch side of the battlefield while over 10,000 men succumbed to contagious diseases. This did not include the high casualties among Indonesians sent to Aceh as forced labour to perform porter, cooking and various other duties. The death toll on the Aceh side was estimated at around

\footnotetext{
${ }^{55}$ NA, MK II, Generaal Overzigt, Missive van Zijne Hoogheid den kommandant van het leger, dd 21 August 1849 no. 4, zeer geheim.

56 J.J.W.E. Verstege (1886) Een beroep op het Nederlandsche volk inzake het Atjeh-vraagstuk, Amsterdam: 124; E.B. Kielstra (1883) Beschrijving van den Atjeh-oorlog: met gebruikmaking der officieele bronnen, door het departement van Koloniën daartoe afgestaan, vol II. Den Haag: 194, 377.
} 
$70,000 .^{57}$ With the total number of casualties estimated at around 100,000, the Aceh War was in a class of its own among the military campaigns in the Dutch East Indies. The surviving Africans, however, served with distinction. Captain A.P. Palmer of the British army in India, who accompanied the Dutch troops in Aceh as an observer, reported that the African troops proved superior. He did not think very highly of the illtrained European troops, nor of the Javanese soldiers, but noted that the African troops instilled a great fear into the Aceh warriors. ${ }^{58}$ Numerous African soldiers earned bronze and silver medals, while some were awarded the highest honour of the Dutch army, the Militaire Willemsorde.

By 1915, there were no more African soldiers serving in the Dutch East Indies army. ${ }^{59}$ Army periodicals reflected on the experience with the African troops with considerable nostalgia. Admittedly, they were impetuous when not treated properly, but who would hold that against them? The Africans were generally praised for their courage, loyalty and stamina. ${ }^{60}$ The Indo-African offspring of the African soldiers remained a permanent feature of the KNIL until the end of colonial rule in 1949. The veterans settled in garrison towns on Java - notably Batavia, Semarang, Purworejo, Salatiga and Solo where their pensions were paid out. Known in Malay as Belanda Hitam (Black Dutchmen), they largely assimilated with the Indo-European population. The Belanda Hitam were indeed legally considered Europeans. They were baptised, mostly in the Catholic Church, spoke Dutch as their mother tongue, attended European schools and qualified for a Dutch passport. Descendants living outside these garrison towns tended to lose touch with the Indo-African communities. It was only in Purworejo that the Africans and their descendants lived together in one part of town, known as Kampung Afrikan (the African village). Purworejo thus became the heart of the Indo-African community on Java, the place where Indo-Africans from others parts of Java would often spend their holidays with relatives.

\footnotetext{
${ }^{57}$ H.L. Zwitser \& C.A. Heshusius (1977) Het Koninklijk Nederlands-Indisch leger 1830-1950, Den Haag: 25 .

${ }^{58}$ P. van 't Veer (1980) De Atjeh-Oorlog, Amsterdam: 94.

${ }^{59}$ Encyclopeadie van Nederlandsch Oost Indië (1917-21), 's Gravenhage: Vol. I: 13-14.

${ }^{60}$ Indische Gids (1886: 611-617).
} 


\section{Indonesian Perspectives}

Source material for the reconstruction of the image of the Africans as seen from an Indonesian perspective is extremely scarce. Most telling, however, is the fact that the Africans and their Indo-African descendants were labelled "Belanda Hitam" (Black Dutchmen) in Malay or "Londo Ireng" (Black White Men) in Javanese. The name Belanda Hitam was already in use around 1850. The African soldiers and their offspring were perceived as part and parcel of the colonial order. It must have been difficult for indigenous Indonesian soldiers in the colonial army to stomach that the African troops qualified for near-European treatment: it seemed an anomaly in a colonial order built on racial hierarchies. Particularly for the Amboinese soldiers, who always enjoyed a privileged position, it was probably incomprehensible that these black newcomers were classified as "Europeans".

The first recorded Indonesian reference to the African soldiers dates from the Padri war on southern Sumatra. In December 1836, KNIL troops, including a detachment of Africans, mounted an assault on the fortified Padri stronghold of Bondjol. The Africans were in the forefront of the invading party. After being captured by the Dutch and exiled to the island of Ambon, the Padri leader, Toewankoe Imam, wrote a detailed report of the event. Toewankoe Imam stressed the barbarous acts perpetrated against his followers. When the army invaded Bondjol, "some African or Buginese soldiers entered without warning the room where the wives of Toewankoe Imam were sleeping, and wanted to drag some women with them. ${ }^{, 61}$ Much turmoil ensued, in which a son of the imam and two of his wives were stabbed in the stomach and buttocks. One woman died of these injuries.

Some indirect evidence can be found in the memoirs of army Colonel W.A. van Rees, who gives a description of the Kedong Kebo mutiny from the perspective of an

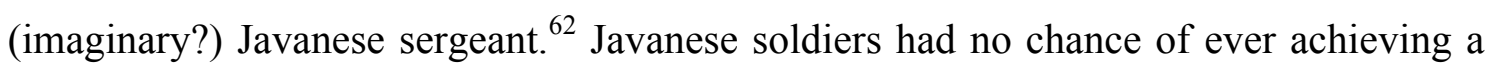
similar status to the Amboinese, who in terms of pay and food were treated almost the same as European troops. Now the KNIL had enlisted Africans who were much blacker

\footnotetext{
61 "Memorie van Toewankoe Imam aangaande de komst der Hollanders in Sumatra's binnenlanden en de aldaar door hen gevoerden oorlog. Vertaald uit het Maleisch" in H.J.J.L. de Stuers (1849) De vestiging and uitbreiding der Nederlanders ter Westkust van Sumatra, Amsterdam: 221-42.

${ }^{62}$ W.A. van Rees (1873) Historisch-Indische schetsen: leesboek voor den militair, Arnhem: 238-58.
} 
even than Javanese, but nevertheless entitled to wear shoes! In the musings of the Javanese sergeant, the Africans are portrayed as bloodthirsty barbarians. A similar image can be seen in the wayang golek puppet depicting an African soldier that is held in the Royal Tropical Museum in Amsterdam.

Around 1978, Indonesian historian Endri Kusruri interviewed former neighbours and servants of the Indo-African settlement in Purworejo. ${ }^{63}$ The enduring impression is one of considerable social distance between the Indo-Africans and the Indonesians. In terms of social status and wealth, the position of the Africans was way above that of the Indonesians. The Indo-Africans were part of European society, although in Javanese eyes they did not quite occupy an equal status with whites. Black skins and frizzy hair were seen as negative attributes, as is evident from the nickname for the Indo-African settlement, gudang areng (charcoal yard). ${ }^{64}$

In the accounts of Indo-African descendants now living in the Netherlands, it is stressed that relations with Indonesian neighbours were generally good. After all, the African grandfathers had lived with Indonesian wives. But in most accounts, the social distance is obvious. As the children went to European schools, their school friends were largely Dutch, Indo-European and fellow Indo-Africans. Most Indo-African families employed one or more Javanese domestic servants. In the socio-cultural hierarchy of the Dutch East Indies, the Indo-Africans were closest to the Indo-Europeans. In due time, they assimilated with the lower echelons of colonial society, although an unknown and undocumented number must have merged with Indonesian society.

In World War II, the second, third and fourth generation Indo-Africans fought in the Dutch army against Japan and shared the fate of the prisoners of war in the notorious camps in Burma. In the Indonesian war of independence (1945-1949), the Indo-Africans encountered the same hostility as the Dutch. The vast majority had never entertained any doubts about the legitimacy of colonial rule and felt no sympathy whatsoever for the nationalist cause. While the Indo-African men served in the Dutch army in the war against Indonesian nationalists, their wives and children were evacuated from Republik-

\footnotetext{
${ }^{63}$ E. Kusruri (1979) "Orang-orang Afrika di Purworejo: Svatu Analisa Historis Sosiologis Atas latar belakang dan peranan mereka", Salatiga (unpublished MA thesis).

${ }^{64}$ M. van Herreveld (2004) "Belanda Hitam: Afrikaan, Indonesiër, Hollander", De Gordel van Smaragd, 24 (1): 11.
} 
held territories to Jakarta and Yogyakarta. After the Dutch finally recognised Indonesian independence in 1949, most Indo-Africans opted for "repatriation" to the Netherlands, in many cases citing that they were "born Dutch" or had "Dutch blood".

\section{Conclusions: Free and Unfree Labour}

Did the use of African troops in the Dutch East Indies army amount to a form of covert slave labour? Or is the deployment of African soldiers in the East Indies more comparable with the mercenary troops used by other European armies, such as the Ghurkas in the British army or the French Foreign Legion? The dichotomy free-unfree labour is not very helpful when trying to contextualize the position of the Belanda Hitam. In the context of the $19^{\text {th }}$ century colonial world, where unfree labour was the rule rather than the exception, it makes more sense to situate the African soldiers somewhere halfway on a sliding scale. Free labour is located at one end of this scale, and slavery at the other end, with conditions of debt bondage, pawns, convict labour and contract labour somewhere in-between.

Most labour required various degrees of coercion. The production of export crops on Java relied on a system of forced cultivation: Javanese villages had to pay their taxes to the Dutch government in coffee and sugar. In the early days of the rubber and tobacco plantations on Eastern Sumatra, conditions for contract workers resembled the exploitation on plantations worked by slave labour. The Dutch colonial army relied heavily on the use of Indonesian convict labour for porterage and other physically demanding work. A substantial part of the Dutch colonial army was made up of mercenary soldiers from Europe, notably from Switzerland, Belgium and Germany. Attempts were made to hire entire regiments from Swiss cantons or German principalities so as to avoid the tiresome process of recruiting individual soldiers. If an entire regiment was hired, the individual soldiers had no say in the matter. Hence the question arose in the discussion about African recruitment: can we regard Negroes as Swiss? Or in other words: is it permissible to make an agreement with a ruler about the collective hire of his manpower? Even for the Dutch soldiers, enlistment in the colonial army was often not voluntary: they were deserters from the Dutch national army, recruited from penal battalions, convicts who were faced with the choice of serving their sentence or enlisting in the colonial army, or penniless young men who signed up in a drunken daze. Although they cannot be labelled slave labour, in some cases their 
options were almost as limited as those of the African recruits who were faced with the choice between remaining slaves in Africa or becoming soldiers on Java.

Although the African soldiers had limited options at the point of recruitment, they had a real choice after the expiry of their contract. Those who settled on Java, or who signed up for another term of army service, did so out of their own volition. Those who opted for repatriation, were shipped to Elmina at the expense of the Dutch government. Their experience resembles the conditions of contract labour or indentured workers, not of slave labour. The fact that the African soldiers were trained to fight and were in possession of weapons also posed obvious limitations to their exploitation. This, as we have seen, is the paradox of colonial armies: in order to secure the loyalty of the colonial troops and to prevent fraternisation with the colonial subjects, soldiers enjoyed certain privileges designed to maintain an esprit de corps and a sense of superiority vis$\grave{a}$-vis the indigenous population. Once the Africans identified with their role as "European soldiers", they were then lambasted as arrogant and insolent and put into their place.

\section{Nature or Nurture : Martial Races and European Civilisation}

The discussions among Dutch government and army officials serve as an interesting illustration of a $19^{\text {th }}$ century debate on "Nature or Nurture". While some considered Africans a "martial race", others argued that intensive training and guidance by European officers was essential to mould them into useful soldiers. Most labour needs in the East Indies were met by indentured labour from China, but the Chinese were seen as coolies, not as potential soldiers. In the search for "martial races", many colonial armies went for the physically imposing Africans. Africans were depicted as the stereotypical warrior race, at least as long as they were "pure Africans", who had not yet been spoilt by European civilisation. The Dutch preferred the Ashanti from the interior to the coastal Fanti who supposedly had assimilated all the vices of the whites along the coast, notably drunkenness and idleness. The "children of nature" from the interior were reputed for their strength, endurance, loyalty and their resistance to tropical diseases. Availability, however, was a crucial factor: when it turned out that Ashanti recruits were not available, the "Donkos" were advertised as the eminent warrior tribe. This is somewhat incongruous, as "Donko" was a generic term for the ethnicities north of Ashanti, where the Ashanti collected their slaves as tribute or war booty. While the 
European influence on the West African coast was considered harmful, the exposure of the African recruits to Dutch influence in the East Indies presumably served a civilising mission. One Dutch official in The Hague advocated the formation of a separate African corps, in order to protect the Africans from the depravities characteristic of European troops in the tropics, but army command in Batavia rejected this idea as impractical and a security risk. ${ }^{65}$ Paradoxically, the instruction of coastal Africans who were used to Europeans was much easier than training the supposedly unspoilt "children of nature".

Over the period of African recruitment, the stereotypical image shifted from brave and loyal soldiers to mutinous rabble, unfit for battle. In retrospect, the image of loyal and courageous troops prevailed, but it was linked to the civilising mission supposedly exercised by the army. "The Netherlands Indies did not have more loyal citizens than these descendants of Cham, who enjoyed their meagre pensions with their 'Mina' and their children in kampong 'Elmina' or 'Afrika' in Salatiga, Batavia, Gedong Kebo or elsewhere. Who made these savages so manageable? Who else but the army?"66 Allocating European status to African troops was not inspired by enlightened notions about racial equality, but by considerations of expediency. The colonial army saw (near) equal treatment as a device to ensure the loyalty of the African troops and to prevent fraternisation with the Indonesian population. By and large, this strategy had the desired effect: the Belanda Hitam and their descendants strongly identified with their role as Dutch soldiers.

\section{Bibliography}

Akurang-Parry, K. (2001) "We Cast about for a Remedy: the Opposition of the Gold Coast Press to the Chinese Mine Labour Experiment in the Gold Coast, ca. 1874-1914", The International Journal of African Historical Studies, 34 (2): 365-84.

Armstrong, J.C. \& Worden, N.A. (1988) “The Slaves, 1652-1834”, in R. Elphick \& H. Giliomee (eds.) The Shaping of South African Society, 1652-1840, Middletown, Conn.

Barendse, R. (2002) The Arabian Seas: the Indian Ocean World of the Seventeenth Century, Armouk N.Y.

\footnotetext{
${ }^{65}$ NA, MK II, Generaal Overzigt, bijlage La G, Pro Memorie aan den heer secretaris-generaal bij het ministerie van koloniën.

${ }^{66}$ Indisch Militair Tijdschrift (1881:379-80).
} 
Blussé, L. (1997) Bitters bruid: een koloniaal huwelijksdrama in de gouden eeuw, Amsterdam.

Breman, J. (1989) Taming the Coolie Beast: Plantation Society and the Colonial Order in Southeast Asia, Delhi.

Buckley, R.N. (1979) Slaves in Red Coats: the British West India Regiments 17951815, New Haven.

Echenberg, M. (1991) Colonial Conscripts: The Tiralleurs Sénégalais in French West Africa, 1857-1960, Portsmouth, New Haven.

Ellis, A.B. (1885) History of the $1^{\text {st }}$ West India Regiment, London.

Encyclopeadie van Nederlandsch Oost Indië (1917-21) (9 vols.) 's Gravenhage.

Gedenkboek KNIL (1961) uitgegeven in opdracht van de Vereniging van OudOnderofficieren van het Koninklijk Nederlands-Indisch Leger Madjoe, ter gelegenheid van haar 50-jarig bestaan, s.1.

Gedenkschrift Koninklijk Nederlandsch-Indisch Leger 1830-1950 (1990), Dordrecht.

Haan, F. de (1922-23) Oud-Batavia, gedenkboek uitgegeven door het Bataviaasch Genootschap van Kunsten en Wetenschappen naar aanleiding van het driehonderdjarig bestaan der stad in 1919, drie delen, Batavia.

Harris, J.E. (1982) Global Dimensions of the African Diaspora, Washington.

Herreveld, M. van (2004) "Belanda Hitam: Afrikaan, Indonesiër, Hollander”, De Gordel van Smaragd, 24 (1): 10-13.

Heshusius, C.A. (1986) KNIL 1830-1950: een fotodocumentaire over het dagelijks leven van het koloniale leger in Nederlands Indië, Houten.

Indische Gids (1886) "Iets over de militaire politiek in Indië”, I: 611-617.

Anonymous (1881) "Het behoud van het Afrikaansche element bij het Indische Leger", Indisch Militair Tijdschrift 12 (1-6): 372-86.

Japin, A. (2001) The Two Hearts of Kwasi Boachi, London.

Kalff, S. (1929) "Inlanders en Afrikanen in het O.I. leger", Indisch Militair Tijdschrift, 51: 779-88.

Kessel, I. van (2003) "African mutinies in the Netherlands East Indies: a nineteenth century colonial paradox", in J. Abbink, M. de Bruijn \& K. van Walraven, (eds.), Rethinking Resistance: Revolt and Violence in African History, Leiden.

(2005) Zwarte Hollanders: Afrikaanse soldaten in Nederlands Indië, Amsterdam.

Kielstra, E.B. (1883) Beschrijving van den Atjeh-oorlog: met gebruikmaking der officieele bronnen, door het departement van Koloniën daartoe afgestaan, Vol. II, Den Haag.

Knaap, G.J. (1995) "Slavery and the Dutch in Southeast Asia", in G. Oostindie (ed.) Fifty Years Later: Antislavery, Capitalism and Modernity in the Dutch Orbit, Leiden.

Kusruri, E. (1979) "Orang-orang Afrika di Purworejo: Svatu Analisa Historis Sosiologis Atas latar belakang dan peranan mereka", Salatiga (unpublished MA thesis).

— (2001) The dynamic of Immigrant People from Africa in Purworejo, Salatiga. 
(2002) "Reminiscences of the African community in Purworejo, Indonesia", in I. van Kessel (ed.) Merchants, Missionaries and Migrants: 300 years of DutchGhanaian relations, Amsterdam.

Lange, H.M. (1852) Het Nederlandsch Oost-Indisch Leger ter Westkust van Sumatra (1819-1845), 's Hertogenbosch.

LaTorre, J.R (1976) "Birthplaces of Dutch East Indies Troops 'recruited' in Kumase, 1837-1842”, Asante Seminar 1976, No. 5: 31-42.

Mann, G. (2006) Native Sons: West African Veterans and France in the Twentieth Century, Durham/London.

Northrup, D. (1995) Indentured Labor in the Age of Imperialism, 1834-1922, Cambridge.

Parsons, T.H. (1999) The African Rank and File: Social Implications of Colonial Military service in the King's African Rifles, 1902-1964, Portsmouth, New Haven.

Prasad, K.K. \& Angenot, J-P. (eds.) (2008) TADIA: The African Diaspora in Asia, Bangalore.

Ranjeva-Rabetafika, Y., Baesjou, R. \& Everts, N. (2000) "Of Paper and Men: A Note on the Archives of the VOC as a Source for the History of Madagascar", Itinerario, 24 (1): 45-67.

Rees, W.A. van (1873) Historisch-Indische schetsen: leesboek voor den militair, Arnhem.

Richardson, P. (1984) "Chinese Indentured Labor in the Transvaal Gold Mining Industry, 1904-1910", in K. Saunders (ed.) Indentured Labor in the British Empire, 1834-1920, London.

Segal, R. (2001) Islam's Black Slaves: a History of Africa's other Black Diaspora, London.

Sertima, I. van (1985) The African Presence in Early Asia, New Brunswick, New Jersey.

Shell, R. (1994) Children of Bondage: a Social History of the Slave Society at the Cape of Good Hope 1652-1834, Johannesburg.

Silva Jayasuriya, S. de (2007) “A forgotten Minority: The Afro-Sri Lankans”, African and Asian Studies, 6 (3): 227-42.

— \& Angenot, J-P. (eds.) (2006) "The African Diaspora in Asia: Historical Gleanings", African and Asian Studies, Special Issue, 5 (3/4): 217-397.

— \& Pankhurst, R. (eds.) (2003) The African Diaspora in the Indian Ocean, Trenton, New Jersey.

Stuers, H.J.J.L. de (1849) De vestiging and uitbreiding der Nederlanders ter Westkust van Sumatra, Amsterdam.

Veer, P. van 't (1980) De Atjeh-Oorlog, Amsterdam.

Verstege, J.J.W.E. (1886) Een beroep op het Nederlandsche volk inzake het Atjehvraagstuk, Amsterdam. 
Yarak, L.W (1987) "Kwasi Boakye and Kwame Poku: Dutch-educated Asante 'Princes"" in: E. Schildkrout (ed.) The Golden Stool: Studies of the Asante Center and Periphery, New York.

_ (1996) "New Sources for the Study of Akan Slavery and Slave Trade: Dutch Military Recruitment in the Gold Coast and Asante, 1831-72" in R. Law (ed.) Source Material for Studying the Slave Trade and the African Diaspora: Papers from a conference of the Centre of Commonwealth Studies, Stirling.

Zwitser, H.L. \& Heshusius, C.A. (1977) Het Koninklijk Nederlands-Indisch leger 1830-1950, Den Haag. 